\title{
“Tear Down These Prison Walls!” Verses of Defiance in the Belarusian Revolution
}

\author{
Simon Lewis
}

The ongoing revolution in Belarus is a musical one. ${ }^{1}$ Indeed, the iconic Russian music critic Artemii Troitskii believes the "phenomenal hyperproductivity" of the contemporary protest song scene in Belarus is "like nothing else in world music history." In addition to a huge wave of recorded material, the streets have been humming with protest songs, from traditional Belarusian folk songs such as Kupalinka to the 1980s rock anthem Khochu peremen ("I Want Changes") by Viktor Tsoi's Kino. ${ }^{3}$ Songs can electrify a crowd through a shared performative unisonance, allow individuals to overcome their anxieties, and also provide verbal reference points that consolidate meaning and provide a sense of shared purpose. Or as poet Yuliya Tsimafeeva put it: "A poem read aloud and a song sung in the public space become the weapons of the revolution."

This is clearly what popular video blogger Siarhei Tsikhanouski realized when, in May 2020, he called upon his YouTube subscribers to learn the words to the song Mury ("Walls"), in Belarusian, Russian, or both; "learn it, it will be playing at the squares," he appealed in a video uploaded on May $27 .{ }^{5}$ Mury is a Belarusian version of Polish bard Jacek Kaczmarski’s 1978 song Mury,

The author would like to thank the editors of the cluster, the anonymous reviewer, and Sasha Razor for invaluable comments on earlier versions of this manuscript.

1. This is in contrast to the recent developments in Russia, where "music did not become a dominant form of expression in the 2011-2013 protests"; Mischa Gabowitsch, Protest in Putin's Russia (Cambridge, Eng., 2017), 173. On the other hand, the Baltic revolutions of the late 1980s were dubbed as "singing revolutions," whereby protest music and national symbols fused into a potent mix; see Dario Martinelli, Give Peace a Chant: Popular Music, Politics and Social Protest (Springer e-book, 2017), 89-120; and the documentary film Kaip mes žaideme revoliucija ("How We Played the Revolution”), dir. Giedrė Žickytė (2012).

2. Aleksandr Chernukho, “'Takogo ne bylo v mirovoi istorii, ia porazhen!' Artemij Troitskij pro protestnuiu muzyku v Belarusi," Onliner.by, November 1, 2020, at people. onliner.by/2020/11/01/artemij-troickij (accessed February 1, 2021).

3. Kupalinka is a folk song that became especially popular in the Soviet 1920s after it was adapted and arranged by the poet Mikhas' Charot (1896-1937) and the composer Uladzimir Terauski (1871-1938). Its current politicization is reflected in its origins: both Charot and Terauski were imprisoned and murdered by the Stalinist regime at the height of the Terror.

4. Yuliya Tsimafeeva, "Belarus diary: 'The authorities threaten us. But we see they are afraid," Financial Times, October 1, 2020, at ft.com/content/80ea9a30-4dee-4014b187-07825069967a (accessed February 1, 2021; limited access).

5. "Siarhei Tsikhanouski zaspiavau pa-belarusku pesniu "Razbury turmy mury," YouTube video, 0:46, posted by "symbal.by," May 27, 2020, at youtube.com/ watch?v=OodAzQs80oI (accessed February 1, 2021). The Russian title is Steny rukhnut, "The Walls will Crumble." The lyrics of the Russian version were written by Kirill Medvedev in 2012 and first performed by the group Arkadii Kots.

Slavic Review 80, no. 1 (Spring 2021)

(C) The Author(s) 2021. Published by Cambridge University Press on behalf of the Association for Slavic, East European, and Eurasian Studies. This is an Open Access article, distributed under the terms of the Creative Commons Attribution licence (http://creativecommons.org/licenses/by/4.0/), which permits unrestricted re-use, distribution, and reproduction in any medium, provided the original work is properly cited. doi: 10.1017/slr.2021.24 
which in turn was translated and adapted from the Catalan original entitled L'estaca (“The Stake"), written in 1968 by Luis Llach. ${ }^{6}$ Just as Kaczmarski's song became an anthem of the Polish Solidarity movement, the Belarusian Mury, with lyrics by prolific poet Andrei Khadanovich, has been part of the protest music repertoire since Khadanovich first performed it after the 2010 presidential elections.

[Chorus]

Разбуры турмы муры!

Прагнеш свабоды-то бяры!

Мур хутка рухне, рухне, рухне-

I пахавае свет стары!
Tear down these prison walls!

You want your freedom, take it all!

The wall will soon crumble, crumble, crumble,

And we'll see the old world fall!?

After Tsikhanouski was refused registration as a presidential candidate and later imprisoned, the song gained enormous popularity, being played at the campaign rallies of his wife Sviatlana Tsikhanouskaia, who ran in his place, as well as at mass protests in the aftermath of the rigged election on August 9.

This example, alongside Kino’s Khochu Peremen, shows that trajectories of influence are of course transnational: protest cultures are inherently border-crossing phenomena, with borrowing, adaptation and translation playing crucial roles. ${ }^{8}$ The Belarusian events have drawn inspiration fromas well as influenced-both eastern (especially Russia, but also Armenia's 2018 revolution and Kyrgyzstan's protests of 2020) and western neighbors (especially the central and eastern European events of 1989 [see Bekus in this cluster] but also reverberating in the Polish abortion protests of fall 2020). At the same time, local agency and rootedness in national tradition are vital to widespread mobilization through shared affect.

A specific feature of Belarusian society is that poets often provide the lyrics to songs that become entrenched in the public consciousness: in other words, the "high" culture of poetry easily translates into the "mass" culture of popular music. ${ }^{9}$ This symbiotic relationship between written and sung verse gives the poetic word a rare power. What is specific to the 2020 unrest in Belarus is that fast digital distribution has added a potent ingredient to the mixture.

6. The word in Polish has the stress on the first syllable, Múry, while in Belarusian the stress is on the ending, Murý. L'estaca has also been rendered into many other languages, such as Yiddish, German, and Arabic.

7. Translations are my own unless otherwise indicated. Musicians Alexander Kiss and Siarhei Kosmas arranged and performed the song with Tsikhanouski, and they also added new lyrics to make it specific to Belarus in 2020.

8. See Simon Teune, ed., The Transnational Condition: Protest Dynamics in an Entangled Europe (New York, 2010) and Hara Kouki and Eduardo Romanos, eds., Protest Beyond Borders: Contentious Politics in Europe since 1945 (New York, 2011).

9. In addition to Mury and Kupalinka, well-known songs written by poets include Mahutny Bozha (Natallia Arsenneva) and Pahonia (Maksim Bahdanovich). For a more recent example, a cycle of poems by Uladzimir Niakliaeu was adapted by a collective of rock musicians: "Naka feat. Dzieciuki \& Razbitae sertsa patsana \& Petlia pristrastsiia \& Rostany, Vam,” YouTube video, 2:13, posted by “nakaminsk,” July 7, 2020, at youtube.com/ watch?v=N9v-P2_220I (accessed February 1, 2021). 
YouTube, Telegram, Facebook, and other social media platforms have played a critical role in spreading information and mobilizing public gatherings, but they have also acted as a vital conduit for creative expression. ${ }^{10}$ Poetry, music and music videos, visual art and short films have been posted and spread online, providing a creative effervescence to undergird the prolonged protests. ${ }^{11}$

While protest verse has long been part of the repertoire of contention in Lukashenka-era Belarus, it never previously occupied such a prominent role in mobilizing social movements. In 2010, for instance, the poet Uladzimir Niakliaeu ran as a presidential candidate-and was beaten and arrested on "election" night on his way to a protest-but his verses played a relatively minor role in his campaign. ${ }^{12}$ Ten years later, however, in a much more consolidated social media environment, poetry and music are a crucial instrument for cementing a sense of collective identity among protestors, establishing transnational solidarity, and affecting the emotional regime of Belarusian society. ${ }^{13}$ An important element of this poetic activity is its bilingualism: whereas Belarusian literature has traditionally and until recently placed a premium on the Belarusian language, a new conviviality is emerging, whereby Russian and Belarusian are gaining an equal footing as languages of creative protest. The Belarusian revolution is a movement of civic nationalism, a fact also reflected in its songs.

\section{Old Poems with New(?) Meanings}

Modern Belarusian-language literature began, after a long hiatus in which Polish and Russian were the culturally dominant codes, with verses of national "awakening” by poets such as Frantsishak Bahushevich (1840-1900), Ianka Kupala (1882-1942), and Iakub Kolas (1882-1956). ${ }^{14}$ Poetic works from the early twentieth century have found an uncanny resonance a century on, due to the parallels in the political situations: despite now being a sovereign coun-

10. See Mischa Gabowitsch in this cluster; Maxim Edwards, "How one Telegram channel became central to Belarus' protests," Global Voices, August 18, 2020, at globalvoices.org/2020/08/18/how-one-telegram-channel-became-central-to-belarusprotests/ (accessed February 1, 2021); and Aliaksandr Herasimenka, Tetyana Lokot, Olga Onuch, and Mariëlle Wijermars, “There's more to Belarus's 'Telegram Revolution' than a cellphone app," The Washington Post, September 11, 2020, at youtube.com/channel/ UCWpNrnGc7yYhzdO-kTW4GEg/ (accessed February 1, 2021).

11. US-Belarusian scholar Sasha Razor has collected a rich online collection of public performances of song, the Belarusian Protest Music Archive on YouTube: youtube.com/ channel/UCWpNrnGc7yYhzdO-kTW4GEg/ (accessed February 1, 2021).

12. The campaign's central slogan was a rather prosaic Havary praudu! ("Speak the Truth!”).

13. For an overview of the importance of collective identity to social movements, see Priska Daphi, "Soziale Bewegungen und kollektive Identität. Forschungsstand und Forschungslücken," Forschungsjournal Soziale Bewegungen 24, no. 4 (December 2011), 13-25. On transnationality, see note 9. On "emotional regimes," see Gabowitsch, Protest in Putin's Russia, 67-74.

14. See Arnold McMillin, A History of Byelorussian Literature from its Origins to the Present Day (Giessen, 1977), 77-218, and Simon Lewis, Belarus-Alternative Visions: Nation, Memory and Cosmopolitanism (Abingdon, UK, 2019), 40-43. 
try, a post-dependency narrative of an absence of clear national identity has remained strong. ${ }^{15}$ Alongside the resurgence of the pre-Soviet red-white-red flag, therefore, verses proclaiming a national collective have featured regularly in protest-related online content, such as Kupala's Khto tam idze? ("Who Goes There?," 1905-1907), which also offers an apt description of mass street demonstrations:
А хто там ідзе, а хто там ідзе
У агромністай такой грамадзе?
-Беларусы.
...
А чаго ж, чаго захацелась ім,
Пагарджаным век, ім, сьляпым, глухім?
-Людзьмі звацца. ${ }^{16}$
Say, who goes there? Say, who goes there?
In such a mighty crowd, oh declare?
- Belarusians.
...
And what is it, then, for which so long they pined,
Scorned throughout the years, they, the deaf, the blind?
- To call themselves human. ${ }^{17}$

One video, released by students and faculty of Belarusian State University as a statement of solidarity with victims of police violence, features a series of talking heads wearing white balaclavas, each reciting a segment of this poem. The final line is delivered in unison by all of the readers, and the picture cuts to an image of the participants simultaneously removing their face coverings, thereby performing their transition from oppressed mass to visibility, subjectivity, and "humanness." 18 The act of demasking also sets up a contrast with the riot police $(O M O N)$, known for roaming the streets of Belarusian cities in black balaclavas. This reading of Kupala's verse thus reinforces the narrative of the present-day protests being a moment of national awakening.

Another early poem shared widely through social media was Iakub Kolas's Voraham ("To Our Enemies," 1916), whose address to imperial Russia clearly resonated with Vladimir Putin's overt support of the Lukashenka regime in the aftermath of the falsified elections.

. . .І вы цяпер рукамі ка́та

Гатовы згоду дараваць?

Але ці можна ў вас брата,
....And even you are now prepared,

With your hangman hands,

To concede our acquiescence?

But tell us, brothers, should

15. A classic conceptualization of Belarusian culture bears the telling title "The Code of Absence": Valiantin Akudovich, Kod Adsutnastsi: asnovy belaruskai mental'nastsi (Minsk, 2007). See also David Marples, Belarus: A Denationalized Nation (Amsterdam, 1999).

16. Ianka Kupala, Zbor tvorau u siami tamakh, vol. 1, Vershy, Peraklady 1904-1907 (Minsk, 1972), 257.

17. Adapted from Vera Rich's translation: Like Water, like Fire: An Anthology of Byelorussian Poetry from 1828 to the Present Day, trans. Vera Rich (London, 1971), 48.

18. "A khto tam i dze?," YouTube video, 0:45, pictures and editing by Volha Akulich, posted by "Pavel B.," September 17, 2020, at youtube.com/watch?v=V4qmiB6uMKM (accessed February 1, 2021). 
Скажэце, каіны, прызнаць? Вам не па сіле груз цяжэрны Вайны, што самі вы ўзнялі, Знішчэнне, мах яе бязмерны, Згінота цяжкая зямлі! Не вы дасце народам свята, Не вам пажар вайны заліць! Дык рукі прэч, забойцы, каты! Не вам аб згодзе гаварыць!19
We see in you Cain's essence?

The burden of war is too heavy for you, a weight you lifted yourselves, Immeasurable destruction, The earth's heavy demise.

You are not the ones to free nations, To quench the fire of war, So hands off, killers and torturers! We'll have your words no more.

The continuity of the myth of Slavic brotherhood throughout Soviet times and beyond allows this verse to retain its ironic bite, while the trope of national liberation remains relevant in 2020-both in the domestic context of the attempt to overhaul the dictatorship and in the international realm, where Russian state hegemony over Belarus is clearly felt in Putin's financial and administrative backing of Lukashenka. Kolas also features in a visual meme by the prolific artist Uladzimir Tsesler, who has contributed a multitude of shareable images on various themes related to the protests and police violence. On September 7, he posted a manipulated photograph of the statue of Kolas that stands on a central square in Minsk, in which the poet's stone effigy holds his head in despair. An ironic commentary using Soviet-era monumental art, ${ }^{20}$ the image appears to speak both for the poet as national hero and the late-Soviet statue, both of which, he suggests, condemn the intransigence of the authorities (See Figure 1).

\section{\#Культпратэст \#Культпротест \#Cultprotest}

Although the protests took off in earnest on the night of August 9, cultural resistance to the new round of falsifications had been building up well before. On July 1, more than twenty musicians, writers, actors, and other cultural figures released a video in which they expressed their anger and resentment at twenty-six years of dictatorship, and demanded free elections as well as the release of all political prisoners in Belarus. ${ }^{21}$ The video was distributed through YouTube, Facebook, Telegram, and other social media and accompanied by the hashtags \#культпратэст \#культпротест, and \#cultprotest. Meanwhile, many other cultural figures posted the same 400-word long text on social media, in which they announced that "we, workers of the cultural

19. Iakub Kolas, Zbor tvorau u chatyrnatstsatsi tamakh, vol. 1, Vershy 1898-1917 (Minsk, 1972), 353.

20. The statue was erected in 1972 and designed by the sculptor Zair Azgur (19082000), one of the most prominent official artists in the post-war Belarusian SSR. Kolas himself held an ambivalent position vis-à-vis official Soviet ideology (as did Ianka Kupala): he lived until 1956 and held several prominent positions in the republic, and was celebrated as a Soviet poet; yet his early work especially was far from aligned with Bolshevik ideas.

21. “'Mozhet, khvatit izdevat'sia nad nami, a?' Aktery i muzykanty ob"iavili \#kul'tprotest," tut.by, July 2, 2020, at news.tut.by/culture/691202.html (accessed February 1, 2021) and "Kul'tpratest \#2020\#”, YouTube video, 12:22, posted by “nakaminsk," July 5, 2020, at youtube.com/watch?v=4YpmlgMaaNU (accessed February 1, 2021). 


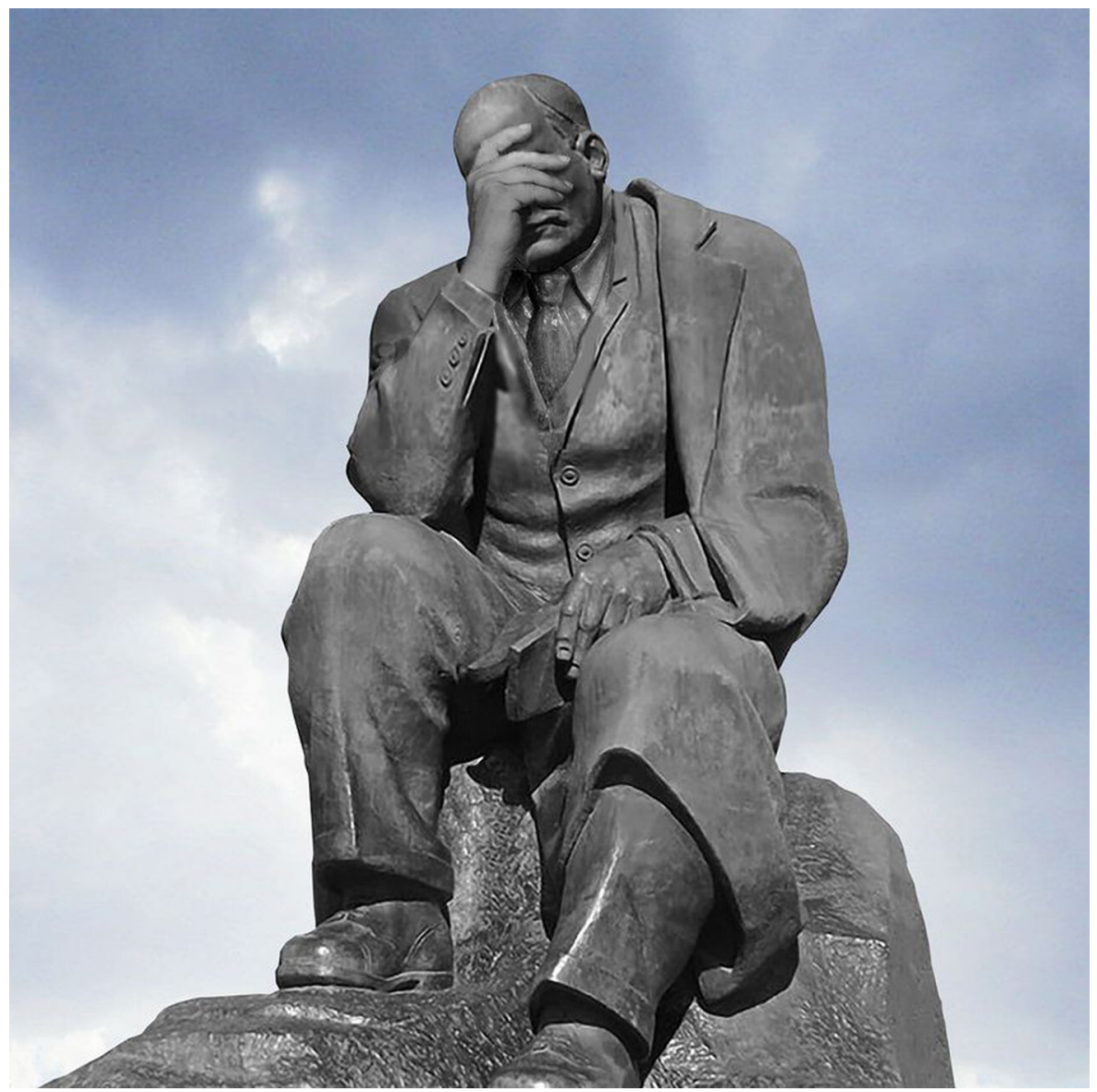

Figure 1. Image of Iakub Kolas monument, posted by Uladzimir Tsesler on September 7, 2020. https://www.facebook.com/vtsesler/posts/2698113283809416.

sphere, declare a \#cultprotest," also using the same Belarusian, Russian, and Romanized versions of the hashtag. The statement continued:

Under the \#cultprotest hashtag, we will do what we do best-create art. And it will be judged . . . by the newly awakened people of Belarus. Our \#cultprotest will sing, shoot videos, draw pictures and hold events for free citizens, not for the authorities we have all had enough of. ${ }^{22}$

Thus, a digital rallying cry was born, which has continued to flourish and adapt as the street protests go on. The website cultprotest.me is a constantly growing repository of protest images that can be shared without restriction,

22. E.g. Andrei Bogomolov, frontman of Minsk-based reggae outfit Botanic Project: Andrew Bogomolov, Facebook post, July 1, 2020, at facebook.com/keshman22/ posts/3134475169972957 (accessed February 1, 2021). See also Andrei Khadanovich, "Belarus: \#cultprotest,” trans. Natalia Mamul, Culture.pl, October 1, 2020, at culture.pl/ en/article/belarus-cultprotest (accessed February 1, 2021). 
and the hashtag accompanies a wide range of creative material, from songs and music videos to poetry and status updates in prose.

The original \#cultprotest video is bilingual, with a clear majority of addresses in Russian. Likewise, the proliferation of creative content under these hashtags and others, or none at all, has reflected the growing ease with which the two official languages of Belarus coexist as languages of cultural expression. The rich variety of protest poetry that has sprung on the personal Facebook pages of poets before being syndicated in online resources and compilations-including as translations into Russian, Polish, Ukrainian, English, and German-has featured verses originally written in both languages, as well as, on occasion, English..$^{23}$ A Russian-language poet such as Dmitrii Strotsev was previously better known and appreciated in Moscow than Minsk, but has emerged as one of the most prominent voices through the energetic immediacy of his verses. For instance, in his Kak udivitel'no ("How Amazing”), written and posted after the mass opposition rally on August 23, he skillfully combines the mundane details of city life with the sensory overload and emotional charge of participating in the event:

\begin{tabular}{|c|c|}
\hline . .ВЗЯВШИСЬ & hand in hand \\
\hline как в последний раз & like last time \\
\hline и вдруг на площади задышать & $\begin{array}{l}\text { and suddenly on the square } \\
\text { breathing }\end{array}$ \\
\hline свободно & freely \\
\hline ключи у соседей & the neighbors have the keys \\
\hline у собаки вода и запас сухарей на сутки & $\begin{array}{l}\text { the dog has water and enough } \\
\text { biscuits for a whole day }\end{array}$ \\
\hline пройти через двор & going through the courtyard \\
\hline где беспечная падает тень & where a reckless shadow falls \\
\hline выйти на улицу & coming out on the street \\
\hline где святая бредёт повседневность & $\begin{array}{l}\text { where holy humdrum } \\
\text { trudges }\end{array}$ \\
\hline может эти двое из всех & $\begin{array}{l}\text { maybe out of everyone these } \\
\text { two }\end{array}$ \\
\hline движутся в наше безумие & are moving into our madness \\
\hline на расстрел & to be shot \\
\hline соскочить & jump \\
\hline ещё ничего не поздно & 's not too late \\
\hline
\end{tabular}

23. In the remainder of this essay, I reproduce (excerpts from) a small selection of poems in order to illustrate some of the variety in themes, styles, and languages of composition that can be seen in recent Belarusian protest poetry. This selection is not intended to be seen as "representative" of any specific movement or the protests as a whole. Poems have been written by award-winning poets (Nasta Kudasava) and lesser-known ones (Hanna Zubkova, who is a visual artist rather than a writer per se); by younger (Hanna Komar, born 1989) and older poets (Dmitrii Strotsev, born 1963); in Russian, Belarusian and English (with translations into other languages following); and for smaller and larger audiences. Some poems have been translated into English already, and thereby gained a degree of international exposure, whereas a great many have not: I translate a poem by Kudasava as an example of the latter. Further work on the diverse and energetic body of contemporary Belarusian protest poetry is certainly necessary, with many more voices waiting to be heard. 
тошнота паническая атака

конечно ты можешь всегда повернуть

назад

глаза и глаза и глаза

шеф усё пропало мы победим

шеф усё пропало мы победим [. . . . ${ }^{24}$ nausea panic attack

of course you can always turn

back

eyes and eyes and eyes

all is lost boss we are going to win

all is lost boss we are going to win $[. . .]^{25}$

Strotsev's strong and highly accessible voice of protest was almost certainly a factor in his arrest on October 21: having disappeared from the streets for several hours, he was registered at Akrestsina prison in Minsk and sentenced to 13 days' imprisonment the following day.

Transnational solidarity is a crucial element of modern social movements. Strotsev's arrest led to calls from several international scholarly associations for his release, and poets have been important figureheads presenting the Belarusian events to an international audience. ${ }^{26}$ Hanna Komar, who was likewise arrested and spent nine days behind bars in September, translates her own Belarusian-language verses into English, and has contributed them to resources such as the Vienna Institute for Human Sciences' invaluable "Chronicle from Belarus": ${ }^{27}$

$\begin{array}{ll}\text { вы скралі мой голас } & \text { you stole my vote } \\ \text { аддайце мой голас! } & \text { give me my voice back } \\ \text { я буду прыходзіць штодня, } & \text { i will come every day } \\ \text { пакуль не пачую яго зноў } & \text { until I can hear it again } \\ & \\ \text { ад рэха маіх крокаў } & \text { let the echo of my footsteps } \\ \text { раструшчцца вашыя } & \text { crack your } \\ \text { бетонныя сцены } & \text { concrete walls } \\ \text { ад папроку ў маіх вачах } & \text { let the reproach in my eyes } \\ \text { разаб’юцца шыбы } & \text { break the glass } \\ \text { вашых пустых вокнаў } & \text { of your empty windows }{ }^{28}\end{array}$

Alongside Komar's lyricism, poets such as Valzhyna Mort, based in the USA, and Yuliya Tsimafeeva have also been active in giving poetic expression

24. Strotsev Dmitry, Facebook post, August 23, 2020, at facebook.com/permalink. php?story_fbid=3810442245636664\&id=100000127774254 (accessed February 1, 2021).

25. Dmitry Strotsev, "How Amazing," trans. Thomas Campbell, The Russian Reader, August 23, 2020, at therussianreader.com/2020/08/23/ (accessed February 1, 2021).

26. "Solidarität mit Dmitri Strozew!," Novinki.de, October 26, 2020, at novinki.de/ solidaritaet-mit-dmitri-strozew (accessed February 1, 2021).

27. Perhaps the most consistent and productive conduit of Belarusian voices abroad is Stimmen aus Belarus, a collaboration between German-speaking scholars and translators, who have translated songs and poetry in addition to news and other diverse forms of expression: facebook.com/Belarusstimmen/ (accessed February 1, 2021).

28. Hanna Komar, "Unprotected / Neabaronenaia," Chronicle from Belarus, at iwm. at/chronicle-from-belarus/unprotected/ (accessed February 1, 2021), also published at penopp.org/articles/unprotected (accessed March 3, 2021). See also "The PEN Pod: Resisting Political Violence and Dictatorship in Belarus with Hanna Komar," Pen America, September 25, 2020, at pen.org/the-pen-pod-hanna-komar/ (accessed February 1, 2021). 
to the protest in English. ${ }^{29}$ Tsimafeeva's first poem composed in English, "My European Poem," appeals directly to international readers by laying bare the peripherality of Belarusian culture and the pain of expressing herself in her own language:

...Sorry, it's a long poem,

Because it's a long story,

I spent more than two thirds of my life

Under the power of the man

I've never voted for,

Who harassed and suppressed and killed

(They say).

And when I come to the literary festivals abroad,

And when I speak English

I try to tell the complicated history of my country

(When I am asked)

As if I am another person,

As if I am like all those European poets and writers,

Who do not have to get used to the thought

That they could be arrested and beaten

For the sake of their country's freedom.

As if I my ugly history is just a harsh story

That I can easily put out from the Anthology of

Modern European short stories because

It's too long,

And too dull.

When I tell it in English,

I want to pretend that I am you,

That I don't have that painful experience

Of constant protesting and constant failing,

That nasty feeling of frustration and dismay.

I want to pretend that I have a hope,

Because when I tell it in Belarusian

I realize, we all realize, there is none

We can look forward to... . ${ }^{30}$

29. Valzhyna Mort, "Belarus protesters surf emotions of exultation and fear," Financial Times, September 9, 2020, at ft.com/content/1b8aa332-24df-4097-9360-39d6adbfc2b1 (accessed February 1, 2021; limited access); Tsimafeeva, "Belarus diary." Mort is also a regular translator of Belarusian poetry into English, see her rendering of Tsimafeeva's Kamen' strakhu (“The Stone of Fear"), Literary Hub, August 14, 2020, at lithub.com/thestone-of-fear/ (accessed February 1, 2021), and translations of poems by Strotsev and Uladzimir Liankevich at lithub.com/the-stone-of-fear/ and penopp.org/articles/prisonpoems/ (accessed March 3, 2021).

30. Yulya Tsimafeeva, "My European Poem," Facebook post, August 5, 2020, at facebook.com/yulya.tsimafiejeva/posts/10217495706600178 (accessed February 1, 2021). Also published on Global Bar Magazine, August 7, 2020, at globalbar.se/2020/08/juliacimafiejeva-my-european-poem/ (accessed February 1, 2021), and (in English) in Andreas Rostek, Thomas Weiler, Nina Weller, and Tina Wünschmann, eds., Belarus!: Das weibliche Gesicht der Revolution (Berlin, 2020), 6-9. 
Shared more than 250 times on Facebook, where Tsimafeeva originally published the poem shortly before the "election," the sincere expression of anguish and yearning also, needless to say, spoke to many Belarusians.

Poetry and music also play a vital role in supplying emotional templates that mediate responses to events: for example, bearing witness to the gross human rights violations committed by Belarusian law enforcement in prisons and detention centers and channeling social outrage. Conceptual artist Hanna Zubkova has authored one of the most striking poetic descriptions of injury in her lengthy "V tom chisle," a Russian-language catalog verse of various corporeal wounds inflicted by the OMON and prison guards:

\begin{tabular}{|c|c|}
\hline . . .проникающее ранение & ...penetrating wounds \\
\hline живота & to the abdomen \\
\hline с эвентрацией & with eventration \\
\hline тонкого кишечника & of the small intestine \\
\hline слепые ранения- & blunt wounds- \\
\hline десятки случаев & dozens of cases \\
\hline открытая травма & external injuries \\
\hline грудной клетки, & to the chest \\
\hline проникающее ранение & penetrating wounds \\
\hline грудной клетки; & to the chest \\
\hline проникающая травма & penetrating trauma \\
\hline грудной клетки & to the chest \\
\hline c повреждением правого & with damage to the right middle \\
\hline среднего долевого & lobar \\
\hline бронха & bronchus \\
\hline и развитием гемопневмоторакса [. . .] & $\begin{array}{l}\text { and the development of } \\
\text { hemopneumothorax... }{ }^{32}\end{array}$ \\
\hline
\end{tabular}

The poem ends with a reference to the first death that resulted directly from police action: Aliaksandr Taraikouski was shot on August 11, 2020. Through its indexing without commentary of these acts of violence, $V$ tom chisle solicits emotional responses that strengthen the protest movement.

Nasta Kudasava, meanwhile, provides an overtly subjective and empathetic reflection on the anxiety and fear of citizens who have lost friends and family:

Тут кожны баіцца прызнацца, што страціў кагосьці, што больш немагчыма без жаху ступаць па зямлі: сасновыя шышкі трашчаць пад нагамі, як косці, як берцы забойцаў, чарнеюць у травах камлі.

А ў небе-нябесныя сотні, нябесныя шэсці. . .

А $з$ неба скрозь слёзы, абняўшы нябесны штурвал, глядзіць ашалелы ад роспачы лётчык Акрэсцін: "Усё

31. Hanna Zubkova, "V tom chisle,” Facebook post, August 18, 2020, facebook.com/ zubkovahanna/posts/3479601078737237 (accessed February 1, 2021).

32. Hanna Zubkova, "Including," trans. Joan Brooks, The Russian Reader, August 23, 2020, at facebook.com/zubkovahanna/posts/3479601078737237 (accessed February 1, 2021). 


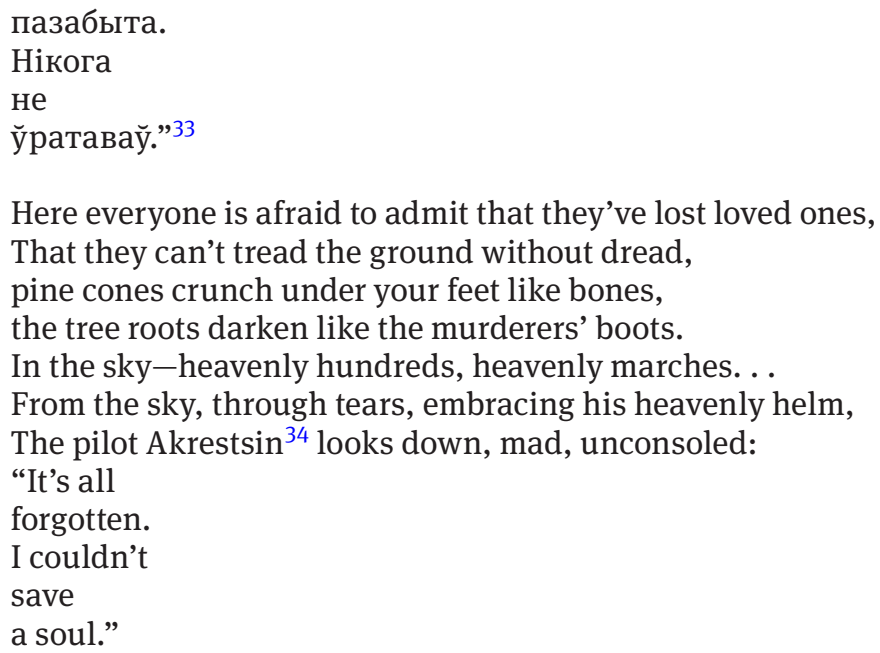

Daily crowds of relatives and friends gathered outside Akrestsina and other prisons, waiting to hear about the fate of their loved ones or attempting to deliver personal packages to prisoners, are an essential component of Belarusian life after August 2020, demonstrating the support networks and social solidarity that galvanize civil society. By providing poetic expression to the emotional ordeal of these citizens, Kudasava also weaponizes grief.

The diversity and ingenuity of creative energy that lies under the surface of the Belarusian revolution is impossible to do justice to in a short text of this format. Musicians have recorded dozens of protest songs in myriad genres, from rap to rock to choral music, with accompanying music videos. ${ }^{35}$ Public performances of song have gone viral, such as a video of the guitarist of 90s cult rock group N.R.M., Pit Paulau, baiting a cordon of riot police with a rendition of the group's iconic protest song Try charapakhy ("Three Tortoises"), joined by a raucous crowd of demonstrators; ${ }^{36}$ or a video of a crowd in a central metro station seemingly spontaneously breaking out into a rendition of Kupalinka and other patriotic songs. ${ }^{37}$ Verses old and new have gained a huge

33. Nasta Kudasava, Facebook post, August20,2020, atfacebook.com/nastakudasawa/ posts/3199127746830040 (accessed February 1, 2021).

34. Barys Akrestsin (Rus.: Boris Okrestin) was a Soviet war hero who died in 1944 near Minsk after crashing his malfunctioning plane into a Nazi squadron. One of the most notorious detention centers of the Lukashenka regime is located on the Minsk street named in his honor, Vulitsa Akrestsina (Okrestin Street).

35. The Russian news portal Meduza has produced a useful early roundup: "Belorusskii protest v muzyke: Pleilist 'Meduzy.' Chto dumaiut o proiskhodiashchem v strane Korzh, Mikhalok i drugie," Meduza, August 16, 2020, at meduza.io/slides/belorusskiy-protest-vmuzyke-pleylist-meduzy (accessed February 1, 2021).

36. "Pit Paulau z hitarai 'shturmue' Palats Nezalezhnastsi," YouTube video, 0:45, posted by "symbal.by," August 23, 2020, youtube.com/watch?v=eopt_IqefTk (accessed February 1, 2021).

37. "Liudi poiut na stantsii metro 'Kupalovskaia' vecherom 27 avgusta," YouTube video, 5:15, posted by “TUT.BY Politika,” 27 August 2020, at youtu.be/TN-ZgjvX_Vc (accessed February 1, 2021). 
significance in generating affect and consolidating collective sentiment. Poets have expressed themselves in Russian, Belarusian, and other languages, using secular and religious imagery, ${ }^{38}$ and the language of children as well as adults. ${ }^{39}$ These verses of defiance, solidarity and empathy, distributed above all by digital means, are an essential component of the revolution-a fact that the authorities themselves tacitly admit when they actively seek out and detain poets and artists. The poets, however, continue to write when they are released; their cultural protest is only strengthened by their penitentiary hardship, and the insurrectionary power of verse grows stronger.

38. For example, Dmitrii Strotsev has incorporated a substantial amount of religious language into many of his poems.

39. See a video appeal by Belarusian children's writers: "Zvarot belaruskikh dzitsiachykh pis'mennikau: Spynitse hvalt!,” YouTube video, 3:10, posted by “Andrei Zhvalevskii," September 27, 2020, youtu.be/Z269kXZme0o (accessed February 1, 2021). 